Nadwa | Jurnal Pendidikan Islam

Vol. 8, Nomor 1, April 2014

\title{
Lingkungan Menyenangkan dalam Pendidikan Anak Usia Dini: Pemikiran Montessori
}

\author{
M. Agung Hidayatulloh \\ Universitas Terbuka UPBJJ Surabaya \\ Email: gung24hidayat@gmail.com
}

\begin{abstract}
This article presents the description of a pleasant environment according to the Montessori method. fun environment characteristics and implications for the sustainability of early childhood education in Indonesia is also a discussion section. Montessori considers the environment as a key children spontaneous learning. Because the child is an active agent in its environment, Montessori suggested that the environment here should be fun for children and also provide opportunities for the development of the potential of each individual. In addition there is ease of access, with full responsibility, and freedom of movement, in the early child hood environment should be designed in such a way to make it look real, natural, and beautiful.
\end{abstract}

Keywords: fun environment, active agent, childhood education

\begin{abstract}
Abstrak
Artikel ini mengetengahkan deskripsi lingkungan menyenangkan menurut metode Montessori. Karakteristik lingkungan menyenangkan dan implikasinya bagi keberlangsungan Pendidikan Anak Usia Dini di Indonesia juga menjadi bagian pembahasan. Montessori menganggap lingkungan sebagai kunci utama pembelajaran spontan anak. Dikarenakan anak adalah agen aktif dalam lingkungannya, Montessori menyarankan agar lingkungan di sini hendaknya yang menyenangkan bagi anak dan juga memberi kesempatan bagi perkembangan potensi masing-masing individu. Di samping ada kemudahan akses, penuh dengan tanggung jawab, dan kebebasan bergerak, lingkungan pendidikan anak perlu didesain sedemikian rupa agar terlihat nyata, alamiah, dan indah.
\end{abstract}

Kata kunci: lingkungan menyenangkan, agen aktif, pendidikan anak.

ISSN 1979-1739

(C) 2014 Nadwa | IAIN Walisongo

http://journal.walisongo.ac.id/index.php/nadwa 


\section{A. Pendahuluan}

Pada suatu waktu, seorang ibu bertanya kepada anak bungsunya yang berumur lima tahun ketika hendak mengajak si anak ke sekolah (Taman Kanak-kanak/TK).

Ibu : "Adik lebih suka mana, di sekolah atau di rumah?"

Anak : (tidak ada jeda, satu kata langsung keluar dari mulut si anak) "Sekolah...!"

Ibu : "Kenapa bisa gitu?"

Anak : "emmm... emmm...." (sang anak tampak kebingungan memberikan jawaban)

Pada kesempatan yang lain, ibu tersebut seperti kesusahan mengajak sang anak ke sekolah.

Ibu : "Adik kok masih tiduran, sudah telat ini. Katanya suka kalau di sekolah?"

Anak : “Aku maunya di rumah saja." (si anak menjawab dengan muka kusut)

Pada percakapan pertama, terdapat indikasi bahwa anak yang sedang duduk di bangku TK itu senang sekali saat ibunya mengajak ke sekolah. Akan tetapi, terjadi 180 derajat perbedaan kondisi sebagaimana terpapar di percakapan kedua. Mengapa demikian? Di antara alasan yang dapat menjawab setting percakapan pertama adalah: 1) di sekolah lebih banyak teman daripada di rumah, 2) di sekolah ditemukan banyak mainan dibandingkan di rumah, atau 3) di sekolah anak lebih bebas bermain daripada di rumah. Sementara alasan berikut bisa dijadikan rujukan untuk menjawab setting percakapan kedua: 1) si anak sempat mendapati hal yang tidak mengenakkan sewaktu di sekolah, 2) letak sekolah berimpitan dengan jalan raya, sehingga suasananya selalu bising, atau 3) kebosanan melanda anak sebab tampilan sekolahnya monoton.

Jika menilik kepada perkembangan zaman sekarang, peristiwa serupa bisa saja berulang terjadi pada dua orang sedarah tersebut. Namun tidak menutup kemungkinan hal yang tak jauh berbeda dialami oleh banyak orang tua di tempat lain. Parahnya, dengan keterbatasan waktu maupun miskinnya pengalaman, terkadang orang tua kesulitan menggali informasi apa penyebab dari dua kondisi sebagaimana percakapan di atas.

Enam contoh alasan yang dipaparkan di atas, sebetulnya cukup memberikan gambaran. Selain keberadaan anak di rumah bersama orang tua, sekolah, dalam hal ini adalah TK, memang memiliki peranan penting bagi pendidikan anak. Ia dianggap rumah kedua, bahkan oleh anak tertentu sekolah dirasakan sebagai rumah 
pertama, melebihi rumah aslinya. Perasaan tersebut dinilai wajar, sebab anak - dengan keunikannya - terkadang menemui kondisi yang membuatnya tidak nyaman ketika berada di rumah, dan sebaliknya. Maka dari itu, di samping dua komponen, yaitu anak dan guru, tidak heran apabila Maria Montessori menekankan pentingnya satu komponen lain, yakni lingkungan menyenangkan, ${ }^{1}$ bagi pendidikan anak usia dini.

Pendidikan anak usia dini sebagai bagian dari penerapan pendidikan sepanjang hayat (life long education) merupakan portal utama menuju level pendidikan berikutnya. Jika tidak dikawal dengan baik, efeknya dapat berkepanjangan. Selain melalui perencanaan, pengorganisasian, dan pengevaluasian pembelajaran yang baik, para pengelola PAUD hendaknya juga tidak mengesampingkan keberadaan lingkungan sebagai setting pembelajaran. Berkenaan dengan hal ini, E. Mulyasa berpendapat bahwa pembelajaran bagi anak usia dini tersusun dari unsur-unsur berupa manusiawi, material, fasilitas, perlengkapan, dan prosedur yang saling mempengaruhi dalam mencapai tujuan pembelajaran. ${ }^{2}$ Menurutnya, pembelajaran akan efektif apabila ditunjang dengan lingkungan dan suasana belajar yang kondusif. Jadi kegiatan bermain yang memberikan kesempatan kepada anak untuk berinteraksi dengan teman dan lingkungannya perlu lebih diprioritaskan. ${ }^{3}$

Dalam penyelenggaraan PAUD, sebaiknya lingkungan diarahkan kepada bentuk yang berkualitas. Sebab, ia merupakan bagian dari sarana dan prasarana yang signifikan. Dalam Peraturan Menteri Pendidikan Nasional Republik Indonesia Nomor 58 Tahun 2009 tentang Standar Pendidikan Anak Usia Dini telah dituangkan bahwa sarana prasarana di PAUD hendaknya memenuhi prinsip-prinsip berikut: 1) aman, nyaman, terang, dan memenuhi kriteria kesehatan bagi anak; 2) sesuai dengan tingkat perkembangan anak; dan 3) memanfaatkan potensi dan sumber daya yang ada di lingkungan sekitar, termasuk barang limbah atau bekas layak pakai.

Dari berbagai uraian di atas, fokus tulisan ini dikerucutkan pada: 1) apa sesungguhnya definisi lingkungan menyenangkan? 2)

\footnotetext{
${ }^{1}$ Meskipun sekolah dan rumah dapat dikatakan sama-sama sebagai bagian dari lingkungan, tetapi tulisan ini memfokuskan istilah lingkungan tersebut hanya kepada lingkungan sekolah (TK).

${ }^{2}$ E. Mulyasa, Manajemen PAUD, (Bandung: Remaja Rosdakarya, 2012), hlm. 60

${ }^{3}$ Mulyasa, Manajemen PAUD..., hlm. 61.
} 
bagaimana gambaran lingkungan menyenangkan menurut pendekatan Montessori? dan 3) apa implikasi lingkungan menyenangkannya Montessori bagi keberlangsungan pendidikan anak usia dini di Indonesia?

\section{B. Riwayat Hidup Montessori}

Montessori lahir pada 1870 di Chiaravalle, sebuah provinsi kecil di Ancona, Italia. Kelahirannya memiliki hubungan yang cukup erat dengan perubahan politik, sosial, dan ekonomi yang disebabkan oleh unifikasi di Italia. Montessori merupakan anak perempuan dari pasangan Alessandro Montessori dan Renilde Stoppani. $^{4}$

Sebagai abdi negara, Alessandro sekeluarga sering berpindah tempat tinggal. Terakhir mereka tinggal di Roma pada 1875 ketika Montessori berusia 5 tahun. ${ }^{5}$ Dikarenakan ia memiliki ketertarikan dan berbakat di bidang matematika, orang tuanya mengajak Montessori pindah ke Roma sehingga ia mendapatkan pengalaman yang lebih banyak di kota besar. Pada perkembangan selanjutnya, ketika sebenarnya ia didorong orang tuanya untuk menjadi seorang guru, Montessori justru mengambil risiko dengan memilih bidang teknik. $^{6}$

Setelah sempat tertarik dengan biologi, Montessori memutuskan untuk belajar ilmu kedokteran. Pada 1896, ia kemudian menjadi wanita pertama di Italia yang mendapatkan gelar Doktor dalam bidang kedokteran. Setelah lulus dari sekolah kedokteran, Montessori tinggal di Klinik Psikiatri, Universitas Roma. Di tempat ini ia menghasilkan karya tentang keterbelakangan mental yang membuat ide-idenya terus berkembang. Keterbelakangan mental, menurutnya, merupakan suatu hal yang lebih dari sekadar permasalahan pedagogik dan kedokteran. Dengan perlakuan pendidikan khusus, orang yang cacat pun bisa ditolong. Pengajaran dan pemahamannya kemudian dikembangkan untuk mengatasi anakanak yang mengalami keterbelakangan mental bawaan. ${ }^{7}$

\footnotetext{
${ }^{4}$ Barbara Isaacs, Bringing the Montessori Approach to Your Early Years Practice, (Oxon: Routledge, 2010), hlm. 5.

${ }^{5}$ Isaacs, Bringing the Montessori Approach ..., hlm. 6.

${ }^{6}$ Elizabeth G. Hainstock, Teaching Montessori in the Home, (New York: Random House), hlm. 5-6.

${ }^{7}$ Hainstock, Teaching Montessori ..., hlm. 6.
} 
Pada 1907, dibangunlah Casa Dei Bambini (Rumah Anakanak) pertama di Via Dei Marsai, San Lorenzo, perkampungan miskin di Roma. Lingkungan ini dibuat dan diperuntukkan bagi anak-anak, terutama anak di bawah 5 tahun. Montessori menggunakan materi yang sebelumnya pernah ia gunakan untuk mengajar anak cacat yang berusia lebih tua. Perhatiannya terhadap Casa Dei Bambini membuat Montessori mempublikasikan Scientific Pedagogy as Applied to Child Education in the Children's Houses pada 1909. Karya tersebut memiliki daya tarik yang cukup tinggi, sehingga orang-orang Amerika memberikan responsnya yang luar biasa. Akan tetapi, ide-ide Montessori sempat mendapatkan celaan, karena Amerika memiliki konsep pendidikan yang mungkin berbeda dan tidak dengan mudahnya menerima suatu perubahan. Banyak orang berpendapat bahwa banyaknya pelatihan demi perkembangan ke depan belum pasti menjamin (keberhasilan) anak usia prasekolah. ${ }^{8}$

Akhirnya pada 1915 Montessori mendapatkan sambutan antusias dari masyarakat Amerika. Ia mengajar dan memberi kuliah para guru di California. Untuk memperkenalkan metodenya ke banyak orang, kelas Montessori kemudian dibentuk di suatu pertunjukan dunia di San Fransisco pada 1915. Sekembalinya ke Eropa, Montessori memberi kuliah di banyak negara. Ia kemudian menghabiskan waktunya untuk penelitian lebih lanjut. Banyak prestasi yang ia raih melalui karya-karyanya. Selama masa perang, ia mendirikan gerakan Montessori di India, yang masih eksis hingga saat sekarang. Montessori meninggal dunia di Belanda pada 1952 dalam usia yang mencapai 81 tahun. Usaha mendiang Montessori kemudian diteruskan oleh putranya, Mario, yang menjadi pimpinan Asosiasi Montessori Internasional dan bermarkas besar di Amsterdam. ${ }^{9}$

\section{Pengertian Lingkungan Menyenangkan}

Lingkungan menyenangkan adalah sesuatu, baik makhluk hidup maupun benda mati, di sekitar individu yang dapat membuatnya senang, bersuka hati, dan terbangkitkan rasa senangnya. Dalam konteks PAUD, lingkungan menyenangkan berarti segala sesuatu yang ada di sekitar anak dan membuat dirinya senang.

${ }^{8}$ Hainstock, Teaching Montessori ..., hlm. 6.

${ }^{9}$ Hainstock, Teaching Montessori ..., hlm. 7. 
Montessori, sama halnya dengan Piaget, menganggap lingkungan sebagai kunci utama pembelajaran spontan anak. Lingkungan di sini hendaknya yang menyenangkan bagi anak dan juga memberi kesempatan bagi perkembangan potensi masingmasing individu. Menurut Montessori, anak adalah an active agent (agen aktif) dalam lingkungannya, sementara guru merupakan fasilitator yang membantu pembelajaran dan perkembangan anak. ${ }^{10}$

Lingkungan, menurut Montessori, menyediakan milieu yang penting di mana manusia berkembang. Pendidikan anak memerlukan sebuah lingkungan di mana ia dapat mengembangkan kekuatan-kekuatan yang ia bawa sejak lahir. Pendidikan dengan demikian adalah sebuah proses kolaborasi dengan watak sang anak dan tahap-tahap perkembangannya. ${ }^{11}$ Interaksi tersebut dan informasi atau pengetahuan yang mereka peroleh kemudian masuk ke dalam dan menjadi bagian dari diri, pengalaman, dan jaringan konseptual sang anak. ${ }^{12}$ Kebebasan aktivitas itu akan mengungkap petunjuk-petunjuk tentang perkembangan sang anak kepada pendidik, mengantar kepada penemuan-penemuan yang memungkinkan untuk merancang sebuah metode pengajaran. ${ }^{13}$

Uraian di atas mengimplikasikan bahwa guru diharapkan memfasilitasi anak dengan menciptakan lingkungan yang menyenangkan agar anak dapat senantiasa menjaga gelarnya sebagai agen aktif. Pembicaraan mengenai lingkungan menyenangkan Montessori akan lebih lengkap apabila kita memperhatikan karakteristiknya yang terkait lima hal.

\section{Karakteristik Lingkungan Menyenangkan}

Lingkungan menyenangkan, menurut perspektif Montessori, memiliki karakteristik sebagai berikut:

1. Accessibility and availability (mudah diakses dan tersedia). Kebanyakan anak menyukai area terbuka yang dapat digunakan untuk berbagai aktivitas individu maupun kelompok. Montessori menganjurkan pula bahwa taman atau area terbuka

${ }^{10}$ Isaacs, Bringing the Montessori Approach...., hlm. 18.

${ }^{11}$ Maria Montessori, The Absorbent Mind, (New York: Henry Holt, 1995), hlm. 89.

${ }^{12}$ Maria Montessori, Metode Montessori: Panduan Wajib untuk Guru dan Orang tua Didik PAUD, editor: Gerald Lee Gutex, terj., Ahmad Lintang Lazuardi, (Yogyakarta: Pustaka Pelajar, 2013), hlm. 73.

${ }^{13}$ Montessori,Metode Montessori ..., hlm. 73. 
hendaknya memiliki area tertutup juga, sehingga memungkinkan untuk digunakan anak dalam berbagai cuaca. Organisasi materi atau alat-alat, aktivitas, dan kesibukan lain juga merupakan aspek lingkungan menyenangkan yang menawarkan ketersediaan dan kemudahan akses. Secara umum, tiap-tiap aktivitas memiliki areanya yang mendukung anak untuk bebas memilih.

2. Freedom of movement and choice (ada kebebasan bergerak dan memilih). Terkait dengan hal ini, guru hendaknya memiliki rasa percaya dan hormat kepada anak. Anak akan bisa menentukan pilihan yang "tepat" jika ia memiliki kesempatan untuk bergerak ke mana pun yang ia suka, dan menemukan apa yang ia butuhkan untuk memuaskan dirinya. Untuk poin kedua ini, Montessori merasa, "...there must be freedom within the prepared environment to develop his physical, mental, and spiritual growth." 14

3. Personal responsibility (penuh tanggung jawab personal). Pemberian kebebasan perlu didukung dengan pelatihan sikap bertanggung jawab kepada anak. Sikap ini bisa dibentuk misalnya dengan melatih seorang anak untuk mengembalikan mainan atau sarana belajar ke tempatnya semula. Anak juga dilatih untuk memiliki kesadaran sosial, yakni kemampuan untuk berbagi dengan sesama.

4. Reality and nature (nyata dan alami). Model nyata seperti benda 3D (tiga dimensi) dianggap lebih representatif daripada 2D (dua dimensi). Misalnya, penggunaan kerangka tubuh manusia berbentuk 3D akan lebih mudah dicerna oleh anak dibandingkan gambar 2D. Contoh lainnya, keberadaan kubus 3D akan lebih mudah dipahami daripada gambar kubus 2D. Kesan alami akan tampak ketika anak diberikan kesempatan lebih untuk bereksplorasi melalui berkebun, kelas alam, dan segala aktivitas yang bersentuhan langsung dengan alam. Kelas indoor pun akan terlihat lebih alami ketika dihiasi dengan bunga atau tanaman yang asli, bukan buatan.

5. Beauty and harmony (indah dan selaras). Aspek keindahan bisa diperoleh misalnya dari dekorasi ruangan yang sederhana, artinya tidak berlebihan dan tidak mengalihkan perhatian anak. Sedangkan kesan selaras bisa didapat dari ketepatan

${ }^{14}$ Hainstock, Teaching Montessori ..., hlm. 9. 
pengorganisasian ruang belajar. Montessori menyarankan agar ruang kelas tidak terlalu sunyi, tetapi juga tidak ramai atau semrawut. Sebagaimana yang ada di Casa Dei Bambini, ruang kelas bagi anak usia 3-6 tahun di sana dinilai menyenangkan, sehingga anak bisa santai dan merasa seperti di rumah sendiri. ${ }^{15}$

\section{E. Implikasi Lingkungan Menyenangkan bagi PAUD}

Jika mencermati keseluruhan ciri-ciri di atas, sesungguhnya aksesibilitas juga berkenaan dengan peletakan alat-alat atau perlengkapan bermain bagi anak. Sarana pembelajaran yang tersedia di kelas sebaiknya mudah dijangkau anak-anak. Artinya, tidak seyogianya anak-anak bersusah payah untuk meraih perlengkapan bermain yang letaknya dua meter lebih tinggi dari jangkauan maksimalnya. Selain dapat mengurangi efisiensi dan efektivitas kegiatan, sulitnya mengakses sarana seperti itu juga bisa menghadirkan rasa putus asa pada anak, sehingga bisa jadi anak tidak mau lagi bermain.

Terkait dengan freedom of movement and choice, guru hendaknya memberi kebebasan bergerak dan memilih kepada anak. Guru perlu memiliki rasa percaya dan hormat kepada anak. Dengan kata lain, anak di sini tidak boleh merasa terhalangi kesempatannya untuk bergerak ke mana pun yang ia suka, karena pada dasarnya anak ingin menemukan apa yang ia butuhkan untuk memuaskan dirinya. Apabila diamati lebih dalam, karakteristik kedua ini berimplikasi bahwa guru (tentunya juga melibatkan pihak lembaga PAUD) perlu menghadirkan ruang gerak bagi anak yang bebas dari segala risiko. Pertama, keamanan mereka harus terjamin. Tidak ada semacam kekhawatiran seperti anak mengalami kecelakaan karena tertabrak kendaraan umum. Tidak ada anak yang terancam bahaya karena mainan ayunan di sekolah berkualitas buruk. Tidak ada ketakutan anak akan dimakan binatang buas, dan lain sebagainya.

Kedua, pemilihan sarana bermain anak. Berkenaan dengan hal ini, telah banyak saran yang masuk kepada para guru (dari berbagai media maupun dari mulut ke mulut) agar cermat dalam memilih sarana itu, terlebih sarana yang bersentuhan langsung dengan anak. Sudah bukan waktunya lagi guru mengutamakan kuantitas, karena ada yang lebih harus diutamakan, yaitu kualitas. Tidak heran apabila ada semacam keharusan bagi para produsen alat permainan

${ }^{15}$ Isaacs, Bringing the Montessori Approach ..., hlm. 20-24. 
PAUD untuk menyesuaikan produknya dengan apa yang distandarkan oleh pemerintah.

Sekitar 70 persen produk mainan anak-anak merupakan barang impor. Untuk melindungi keamanan dan keselamatan anak-anak, mulai bulan ini (Mei) mainan anak-anak impor wajib bersertifikat SNI (Standar Nasional Indonesia). Sementara itu, mainan anakanak buatan UKM (Usaha Kecil Menengah) dalam negeri diberi toleransi pembinaan hingga enam bulan ke depan.

Pernyataan di atas setidaknya menjadi titik terang untuk mengurangi kekhawatiran para orang tua terhadap keselamatan anak-anaknya. Produk dalam negeri saja harus ber-SNI, apalagi yang impor, yang kita sering tidak tahu asal-muasalnya, harus disertai dengan pengawasan penuh. Setiap orang tua tentu ingin yang terbaik bagi anaknya. Mereka tidak berkehendak anaknya menjadi "kelinci" percobaan. Slogan "Untuk anak kok pakai cobacoba" pada sebuah iklan barangkali bisa menjadi penguat untuk selalu menghadirkan yang terbaik bagi sang buah hati.

Untuk mendukung kutipan di atas, Kepala Pusat Pendidikan dan Pemasyarakatan Standarisasi Badan Standarisasi Nasional (BSN), Metrawinda Tunus, menuturkan bahwa tujuan utama pemberlakuan sertifikasi SNI untuk mainan anak-anak murni sebagai bentuk perlindungan kepada mereka. Menurutnya, banyak sekali risiko kecelakaan yang bisa timbul karena mainan. Telah ditetapkan lima SNI yang berkenaan dengan keamanan dan keselamatan anak, yaitu: 1) keamanan yang berhubungan dengan sifat fisik dan mekanis, 2) sifat mudah terbakar, 3) sifat migrasi unsur zat tertentu, 4) keamanan mainan berbasis elektrik, dan 5) keamanan mainan seluncuran dan aktifitas outdoor. Ia mencontohkan, "Mainan anak harus dinilai dari sisi bentuk yang menyangkut keamanan sudut atau kelancipan. Selain itu, untuk urusan migrasi zat kimia, aturan SNI tersebut berkaitan dengan penggunaan kandungan pewarna yang biasa dipakai dalam produk sebuah mainan." 16

Setelah memperhatikan penjelasan karakteristik kedua dari lingkungan menyenangkannya Montessori, akan lebih bijak apabila guru dan pihak sekolah bisa merangkul orang tua untuk memilihkan sarana bermain bagi anak. Pemilihan sarana merujuk kepada lima standar keamanan di atas. Jadi sebelum anak diberi kebebasan untuk

16“"Mainan Anak-anak Wajib Ber-SNI", Jawa Pos, Kamis 22 Mei 2014, hlm. 16. 
menentukan mainannya di sekolah, kita yang lebih dewasa wajib memilihkan mainan yang bebas risiko dan aman untuk mereka. Sebab, Elizabeth B. Hurlock, sebagaimana dinyatakan kembali oleh Suyadi dan Maulidya Ulfah, meyakini bahwa lingkungan yang bebas risiko merupakan arena bermain anak yang memungkinkan mereka beraktualisasi diri secara total, karena tidak ada rasa takut sedikitpun. ${ }^{17}$ Istilah yang digunakan Hainstock di bawah ini barangkali dapat mewakili kebebasan yang dimaksudkan oleh Montessori.

An atmosphere of freedom and liberty of the child is always evident in the Montessori classroom, for Dr. Montessori felt that "the educated hand is a free hand" and that "discipline must come through liberty". The environment in the Montessori classroom is designed to exclude distractions and to offer opportunities for

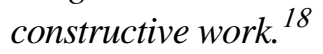

Selanjutnya jika mengingat kembali apa tujuan PAUD sesungguhnya, dalam Undang-undang Republik Indonesia Nomor 20 Tahun 2003 tentang Sistem Pendidikan Nasional telah disebutkan, "Pendidikan anak usia dini adalah suatu upaya pembinaan yang ditujukan kepada anak sejak lahir sampai dengan usia enam tahun yang dilakukan melalui pemberian rangsangan pendidikan untuk membantu pertumbuhan dan perkembangan jasmani dan rohani agar anak memiliki kesiapan dalam memasuki pendidikan lebih lanjut." ${ }^{19}$ Di dalam UU itu tertera bahwa PAUD bertujuan untuk membantu pertumbuhan dan perkembangan jasmani dan rohani anak.

Dari UU itu, implikasi yang berkembang berikutnya adalah kebebasan bergerak yang menjadi salah satu ciri lingkungan menyenangkan-nya Montessori, dan itu perlu didukung pula dengan keamanan rohani anak. Kriminalitas seperti itu tentu dapat berefek negatif bagi perkembangan rohani anak, terutama bagi masa depannya. Dengan contoh kasus yang terjadi di Jakarta International School (JIS), dan ternyata (menurut berbagai sumber) pelakunya melibatkan orang dalam, maka semua pihak yang berkepentingan harus mengevaluasi kinerja semua lini, dan lebih bertanggung jawab lagi untuk bertindak sebagai orang yang senantiasa baik

\footnotetext{
${ }^{17}$ Suyadi dan Maulidya Ulfah, Konsep Dasar PAUD, (Bandung: Remaja Rosdakarya, 2013), hlm. 52.

${ }^{18}$ Hainstock, Teaching Montessori in ..., hlm. 10.

${ }^{19}$ UU RI No. 20 Tahun 2003 Tentang Sistem Pendidikan Nasional, Bab I Pasal 1 Ayat 14.
} 
dengan anak-anak. Padahal di Permendiknas RI No. 58 Tahun 2009 tentang Standar Pendidikan Anak Usia Dini telah didengungkan, bahwa standar sarana dan prasarana PAUD harus memperhatikan prinsip-prinsip seperti: 1) aman, nyaman, terang, dan memenuhi kriteria kesehatan bagi anak; 2) sesuai dengan tingkat perkembangan anak, dan 3) memanfaatkan potensi dan sumber daya yang ada di lingkungan sekitar, termasuk barang limbah atau bekas layak pakai. ${ }^{20}$ Di samping itu Isjoni juga menganjurkan agar suasana belajar (di PAUD) tidak memberikan beban dan membosankan anak, suasana belajar perlu dibuat secara alami, hangat, dan menyenangkan. ${ }^{21}$

Senada dengan Isjoni, Montessori menilai, “...if the child was bored and did not react spontaneously to his work, it was not his fault, but rather the fault of the way the work was presented to him." 22 Jadi bukan salah anak-anak jika mereka merasa bosan dan tidak bereaksi saat diberi tugas di kelas, tetapi cara memunculkan tugas itulah yang seharusnya dikoreksi. Bisa saja karena atmosfer kelas yang kurang nyaman, atau kelas terkesan kurang rapi, sehingga anak-anak bosan.

Karakteristik kedua erat kaitannya dengan karakteristik ketiga. Pemberian kebebasan perlu didukung dengan pelatihan sikap bertanggung jawab kepada anak. Sikap itu bisa dibentuk, misalnya dengan melatih anak untuk mengembalikan mainan atau sarana belajar ke tempatnya semula, sehingga siap digunakan kembali setiap saat dibutuhkan. Anak juga dilatih untuk memiliki kesadaran sosial, yakni kemampuan untuk berbagi dengan sesama. Tentang yang satu ini, Barbara Isaacs menerangkan bahwa lingkungan menyenangkan akan berdampak bagi kemajuan individu, namun bukan berarti kehidupan sosial tidak penting. Maka dari itu, anakanak perlu dilatih berbagi, yang oleh Montessori diistilahkan dengan "the cohesion of the social unit". Dicontohkan:

For Montessori, the Children's House offers family groupings of children, allowing the older, more settled children to model behaviour. They also have the opportunity to become 'teachers' when a younger child needs help or wants to know how to use an activity.

\footnotetext{
${ }^{20}$ Permendiknas RI No. 58 Tahun 2009 Tentang Standar Pendidikan Anak Usia Dini, hlm. 41.

${ }^{21}$ Isjoni, Model Pembelajaran Anak Usia Dini, (Bandung: Alfabeta, 2010), hlm. 57.

${ }^{22}$ Hainstock, Teaching Montessori in ..., hlm. 10.
} 
The older children are often the first ones to remind the younger ones to put away their activity, or to help them with tasks such as putting on shoes or a coat.

Masih berkenaan dengan karakteristik ketiga, sejumlah PAUD di Indonesia tampaknya sudah mengemas aktivitas berbau sosial dengan kegiatan-kegiatan seperti makan bersama. Anak-anak sebelumnya telah diberitahu untuk membawa bekal dari rumah. Jika kebetulan lupa atau tidak sempat dibawakan bekal oleh orang tuanya, anak-anak lain diberi kesempatan untuk berbagi dengan yang bersangkutan. Dengan cara seperti itu, jiwa sosial anak akan semakin terbangun.

Karakteristik lingkungan menyenangkan yang keempat adalah nyata dan alami. Menambahkan keterangan sebelumnya tentang reality, sudah bukan saatnya lagi aktivitas di PAUD berkutat pada kegiatan menghafal penjumlahan yang terkesan abstrak. Intelegensi anak perlu dikonstruksi lebih lanjut dengan bantuan benda-benda konkret. Simbol 2+2 di papan tulis harus dikonkretkan dengan misalnya 2 apel ditambah 2 apel.

Sementara untuk ke-alami-an lingkungan, dalam The Montessori Method, Montessori memberikan pengantar dengan sebuah kisah seorang anak yang dibunuh dan dibuang di alam liar. Meski akhirnya anak itu hidup, tapi ia tidak dapat berkomunikasi seperti halnya manusia pada umumnya. Ketika ditemukan oleh pemburu dan dibawa ke Paris, ia dianggap idiot. Padahal ia memiliki kelebihan, yaitu jiwanya telah menyatu dengan alam. Dengan kemampuan itu pula ia terbebas dari binatang buas. ${ }^{23}$

Yang perlu digarisbawahi adalah, setiap anak yang dilahirkan dari rahim seorang ibu memiliki lingkungan alamiah, yakni keluarga. Sayangnya, anak liar pada cerita itu dipaksa untuk pindah ke lingkungan alamiah yang lain, yaitu alam (bebas). Montessori kemudian menekankan peran edukatif orang-orang di sekitar agar tidak mengambil anak kecil secara mendadak, ataupun dengan paksaan dari ibunya untuk dimasukkan ke sekolah, atau bahkan alam liar. Itulah yang telah diupayakan oleh "The Children's Houses"-nya Montessori. Anak-anak dididik untuk tidak jauh dari ibunya. Di samping itu mereka diberi kesempatan untuk tumbuh di udara terbuka, di kebun-kebun dan taman-taman, atau dibiarkan

${ }^{23}$ Maria Montessori, The Montessori Method: Scientific Pedagogy as Applied to Child Education in "The Children's Houses", (New York: Frederick A. Stokes Company, 1912), hlm. 149. 
selama berjam-jam dengan setengah telanjang di pantai, terpapar sinar matahari. "The best means of invigorating the child is to immerse him in nature. ${ }^{24}$ Cara terbaik untuk memperkuat anak adalah dengan membiasakannya bergaul dengan alam. Misalnya, guru dapat membimbing anak untuk menyentuh sekaligus mengamati bermacam-macam daun, tangkai, ranting, dan pepohonan. Sesekali ajak anak untuk menikmati terik matahari sembari memberi makan unggas.

Di samping kehidupan fisik, anak perlu bersentuhan dengan kekuatan-kekuatan stimulus dari alam. Untuk kehidupan psikisnya kita perlu juga menempatkan jiwa anak-anak kita untuk bersentuhan dengan semua ciptaan Tuhan. Dengan begitu anak dapat mengambil banyak manfaat dari daya-daya pendidikan langsung dari alam hayati. The method for arriving at this end is to set the child at agricultural labour, guiding him to the cultivation of plants and animals, and so to the intelligent contemplation of nature. ${ }^{25}$ Melibatkan anak dalam kegiatan bercocok tanam dan beternak dianggap sebagai contoh metode yang tepat untuk mendekatkannya dengan Tuhan. Lebih detail mengenai langkah-langkah dan maksud dari metode tersebut adalah:

1. The child is initiated into observation of the phenomena of life. Anak didorong untuk mengamati fenomena kehidupan. Secara praktis, dengan sikap yang penuh penghargaan, memberi kesempatan anak untuk melihat bagaimana tumbuhan dan hewan "beraktivitas". Ajak anak melihat kucing menggendong anak-anaknya. Hadirkan rekaman burung yang memberi makan sarapan buah hatinya. Atau sajikan kegiatan yang memperlihatkan indahnya perubahan dari ulat ke kupu-kupu, dari bibit menjadi tanaman, dan lain-lain. Dengan cara seperti itu pula anak dapat secara logis dirangsang untuk menghargai kepedulian dan perawatan yang telah diberikan oleh ibu kepadanya.

2. The child is initiated into foresight by way of auto-education. Auto-edukasi bisa menjadi sarana melihat masa depan. Ketika anak tahu bahwa kehidupan tanaman bergantung pada kepeduliannya untuk mengairi mereka dan kehidupan hewan amat bergantung kepada ketekunan si anak memberi makan-yang

\footnotetext{
${ }^{24}$ Montessori, The Montessori Method ..., hlm. 154.

${ }^{25}$ Montessori, The Montessori Method ..., hlm. 155.
} 
tanpa itu tanaman kecil akan mengering dan hewan-hewan kelaparan, maka sang anak akan waspada dan mulai menyadari sebuah misi dalam kehidupan. Penghargaan-penghargaan yang diperoleh anak juga tetap ada, antara dia dan alam. Satu hari yang cerah setelah pemeliharaan panjang dan sabar dalam memberi makanan dan jerami kepada merpati-merpati yang sedang mengerami telur-telurnya.

3. The children are initiated into the virtue of patience and into confident expectation, which is a form of faith and of philosophy of life. Anak-anak didorong untuk sabar dan memiliki asa yang kuat, yang merupakan sebuah bentuk keyakinan dan filosofi kehidupan. Pada saat anak-anak memasukkan sebuah biji ke dalam tanah, menunggu hingga ia tumbuh, melihat penampakan pertama dari tumbuhan yang belum berbentuk, menunggu pertumbuhan dan transformasinya menjadi bunga dan buah, melihat bagaimana sebagian tanaman tumbuh lebih cepat dan lebih lambat, bagaimana tumbuhan berganti daun dan berbuah, maka anak akan menyemai benih-benih kebijaksanaan yang dihadirkan oleh Sang Pengolah tanah, bahwa ia harus sabar dan berkeyakinan kuat, termasuk dalam segala hal.

4. The children are inspired with a feeling for nature, which is maintained by the marvels of creation. Anak-anak terinspirasi dengan sebuah rasa terhadap alam, dan rasa itu dipelihara oleh keajaiban-keajaiban penciptaan yang terlihat di alam. Ketika anak meletakkan sebutir biji atau segumpal umbi dan rutin menyiraminya, pada waktunya panen akan terlihat bahwa alam membalas usaha keras sang anak dengan adanya buah yang dapat dinikmati. Berbeda halnya bila anak mengumpulkan buah-buah materil dari kerjanya, benda-benda seragam yang tak bergerak, yang dikonsumsi dan dihabiskan daripada ditingkatkan dan dilipatgandakan.

5. The child follows the natural way of development of the human race. ${ }^{26}$ Anak mengikuti cara perkembangan alami dari ras manusia. Pendidikan sebagai upaya mendekatkan anak dengan alam) membuat perkembangan anak harmonis dengan perkembangan alaminya sebagai manusia. Implikasi kuat yang terbangun dari karakteristik keempat di atas adalah anak-anak di PAUD sebaiknya diberi kesempatan untuk mengenal ke luar,

${ }^{26}$ Montessori, The Montessori Method ..., hlm. 156-160. 
yakni lingkungan sekitar, dunia nyata. Tidak bisa dipungkiri karena mereka merupakan bagian dari lingkungan tersebut, dan sejak dini harus diupayakan beradaptasi dengan lingkungan.

Berhubungan dengan karakteristik (lingkungan menyenangkan) kelima, Hainstock mengulas pendapat Montessori melalui pernyataannya, "Realizing that the child's aesthetic sense is developed in the early years, Montessori stressed the importance of beauty in the classroom. Montessori materials are always well made and well maintained, and neatly arranged on their shelves. The walls are hung with attractive pictures, and numerous books are available to the child. Everything in the classroom has a specific use, and there is nothing there that the child cannot see and touch, for this is how he learns. "Jiwa estetis anak berkembang pada masa usia dini. Kelas yang indah pun menjadi penting. Indah, sesuai dengan penjelasan Barbara Isaacs, bukan berarti penuh dengan hiasan warna-warni. Buatlah dekorasi ruangan yang sederhana dan tidak mengalihkan perhatian anak. Di sisi lain, istilah harmoni direpresentasikan dengan organisasi ruangan dan perlengkapan.

Begitulah penjelasan mengenai lingkungan menyenangkannya Montessori. Apabila kelima karakteristik sebagaimana terungkap di atas ada di semua lembaga PAUD di Indonesia, bahkan dunia, niscaya anak-anak akan menemukan "surga firdaus" di dunia. Mereka tentu betah untuk berlama-lama, bermain dan belajar. Bukankah telah digambarkan dalam berbagai literatur, bahwa di surga firdaus semua yang dibutuhkan para penghuninya tersedia dan mereka mudah mengaksesnya? Mereka juga bebas bergerak dan memilih jalannya tanpa harus takut ditilang polisi, bukan? Dan lagi, surga itu nyata nan indah, full of harmony.

\section{F. Penutup}

Lingkungan menyenangkan dalam konteks PAUD adalah segala sesuatu, baik makhluk hidup maupun benda mati, di sekitar anak yang dapat membuatnya senang, bersuka hati, dan terbangkitkan rasa senangnya. Montessori mencirikan lingkungan menyenangkan itu dengan ketersediaan dan kemudahan akses, kebebasan bergerak dan memilih, penuh tanggung jawab personal, nyata dan alami, serta indah dan selaras. Implikasinya, perlengkapan di PAUD sebaiknya tidak sulit dijangkau anak dan selalu ada ketika dibutuhkan. Anak juga tidak seharusnya dibiarkan merasa terkungkung dalam ruangan yang serba terbatas. Luangkan waktu 
bagi anak untuk bersinggungan dengan dunia nyata dan alami, bukan bentukan manusia yang terlempar dari kesan natural, apalagi abstrak. Biarkan anak melatih kemandirian dan tanggung jawabnya, yaitu jauh dari intervensi yang tidak perlu dari orang dewasa. Tempat belajar yang sederhana, indah, dan selaras lebih baik bagi anak, daripada tempat yang glamour atau dipenuhi dengan gemerlapnya hiasan.

\section{Kepustakaan}

Hainstock, Elizabeth G., Teaching Montessori in the Home (New York: Random House, t.t.)

Isaacs, Barbara, Bringing the Montessori Approach to Your Early Years Practice, (Oxon: Routledge, 2010).

Isjoni, Model Pembelajaran Anak Usia Dini, (Bandung: Alfabeta, 2010).

"Mainan Anak-anak Wajib Ber-SNI", Jawa Pos, (Kamis, 22 Mei 2014).

Montessori, Maria, Metode Montessori: Panduan Wajib untuk Guru dan Orang Tua Didik PAUD, editor: Gerald Lee Gutex, terj. Ahmad Lintang Lazuardi, (Yogyakarta: Pustaka Pelajar, 2013).

Montessori, Maria, The Montessori Method: Scientific Pedagogy as Applied to Child Education in "The Children's Houses", (New York: Frederick A. Stokes Company, 1912).

-----, The Absorbent Mind, (New York: Henry Holt, 1995).

Mulyasa, E., Manajemen PAUD, (Bandung: Remaja Rosdakarya, 2012).

Suyadi dan Ulfah, Maulidya, Konsep Dasar PAUD, (Bandung: Remaja Rosdakarya, 2013).

Pemerintah R.I., Peraturan Menteri Pendidikan Nasional Nomor 58 Tahun 2009 tentang Standar Pendidikan Anak Usia Dini.

Pemerintah R.I., Undang-undang Republik Indonesia Nomor 20

Tahun 2003 Tentang Sistem Pendidikan Nasional. 
